Thorax (1960), 15, 240.

\title{
OBSERVATIONS ON 100 CASES OF BRONCHIAL CARCINOMA IN A RURAL AREA
}

BY

\author{
B. R. HILlIS* AND J. A. CAMERON \\ From Lochmaben Chest Hospital, Dumfriesshire
}

(RECEIVED FOR PUBLICATION APRIL 6, 1960)

There is little exact information concerning the incidence and type of bronchial carcinoma in rural areas. A.s regards incidence, Stocks (1959a) has suggested that there is a marked excess in the towns as compared with the country. As regards type, there is no information available to show what histological variation, if any, is demonstrable in rural as compared with urban cases. If such quantitative or qualitative changes could, in fact, be identified, it would clearly be important to know whether they reflected differences in smoking habits, occupation, or atmospheric pollution, or were possibly even related to factors as yet unknown.

The present investigation was carried out in order to answer these questions. It was based on the analysis of 100 cases of bronchial carcinoma arising in the permanent population of the rural area of Dumfries and Galloway during six years between 1953 and 1959. The results were compared with those recorded by other authors employing similar methods of investigation in urban areas.

Dumfries and Galloway had an estimated population of 147,726 in 1956. Agriculture and associated occupations are its main concern. C nly country towns are found in the area, and there are no heavy industries. Atmospheric pollution is negligible or very low. No special hazards predisposing to bronchial carcinoma are known to exist in the area.

In the series the diagnosis of bronchial carcinoma was established by bronchoscopy in all patients, and histological confirmation obtained by biopsy at bronchoscopy or at thoracotomy in $78 \%$. There was a certain selection, as bronchoscopy was only done if it was likely that information would be obtained that would influence the management of the patient. Even so, the findings are thought to be true of bronchial carcinoma in the area as a whole. During the period under review all the diagnostic bronchoscopies in the area were done in this unit, under standard conditions, and the unit was actively concerned in all aspects of respiratory

\footnotetext{
* Present address: Stobhill General Hospital, Glasgow.
}

diseases diagnosed locally. It is estimated from figures supplied by the Registrar-General for 1953 to 1958 that at some time in the illness the unit was consulted about more than $65 \%$ of all patients in the area certified as dying from bronchial carcinoma, and in the case of virtually all who received thoracic surgical treatment.

TABLE I

DISTRIBUTION BY SEX AND AGE

\begin{tabular}{|c|c|c|c|c|c|c|c|c|}
\hline \multirow{2}{*}{ Sex } & \multicolumn{6}{|c|}{ Age Groups (Years) } & \multirow{2}{*}{ Total } & \multirow{2}{*}{$\begin{array}{l}\text { Sex } \\
\text { Rati } \\
\end{array}$} \\
\hline & $\begin{array}{c}\text { Under } \\
35\end{array}$ & $35-44$ & $45-54$ & $55-64$ & $65-74$ & $\underset{74}{\text { Over }}$ & & \\
\hline $\begin{array}{l}\text { Male .. } \\
\text { Female }\end{array}$ & $\begin{array}{l}2 \\
1\end{array}$ & $\begin{array}{l}7 \\
2\end{array}$ & $\begin{array}{r}23 \\
3\end{array}$ & $\begin{array}{r}48 \\
2\end{array}$ & $\begin{array}{r}10 \\
0\end{array}$ & $\begin{array}{l}2 \\
0\end{array}$ & $\begin{array}{r}92 \\
8\end{array}$ & $\begin{array}{r}11.5 \overline{\bar{Q}} \\
1.0 \frac{\bar{\partial}}{\partial}\end{array}$ \\
\hline
\end{tabular}

It is generally accepted that bronshia! ca cinoma is commoner in men (Bignall, 1958a). In the present rural series the male: female ratio $(11.5: 1.0)$ was similar to that obtained in clinical series in urban, or predominantly urban, areas, for example, in the Manchester area $13: 1$ (Nicholson, Fox, and Bryce, 1957); in the North of England and Midlands 9 : 1 (Mason, 1949); in patients who survived operation in the London area 10 : 1 (Bignall and Moon, 1955); and in a necropsy series in the Greater London area $6: 1$ (Bryson and Spencer, 1951).

In the present series $77.2 \%$ of the male cases were detected between 45 and 64 years of age, and in the predominantly urban series of Mason (1949) $69.5 \%$ of males were between 40 and 60 years of age. The average age of all cases in the present series was 55 years, the same as that in the urban series of Nicholson et al. (1957). In Bryson and Spencer's clinical and pathological survey in the London area (1951) the average age of death in both sexes was 59.5 years.

Many diverse occupations are associated with a high rate of bronchial carcinoma, including the mining of certain radioactive ores, the refining of nickel, the manufacture of chromates and of 
TABLE II

DISTRIBUTION BY OCCUPATION

\begin{tabular}{|c|c|c|c|c|c|}
\hline \multicolumn{4}{|c|}{ Occupations Basically Indoor } & \multicolumn{2}{|c|}{ Occupations Basically Outdoor } \\
\hline $\begin{array}{l}\text { Housewives } \\
\text { Bakers . } \\
\text { Clerical } \\
\text { Professional } \\
\text { Miscellaneous }\end{array}$ & $\begin{array}{l}\cdots \\
\cdots \\
\cdots \\
\cdots\end{array}$ & $\begin{array}{l}\cdots \\
\cdots \\
\cdots \\
\cdots\end{array}$ & $\begin{array}{r}7 \\
4 \\
4 \\
3 \\
21\end{array}$ & $\begin{array}{l}\text { Labourers } \\
\text { Building trade workers } \\
\text { Farm workers } \\
\text { Railway (non-clerical) } \\
\begin{array}{l}\text { Motor vehicle drivers or } \\
\text { mechanics }\end{array} \\
\begin{array}{lll}\text { Miners .. } & \ldots & \ldots \\
\text { Miscellaneous } & \ldots & \ldots\end{array}\end{array}$ & $\begin{array}{r}13 \\
10 \\
8 \\
7 \\
7 \\
7 \\
11\end{array}$ \\
\hline Total & & . & $39(\%)$ & & $61(\%)$ \\
\hline
\end{tabular}

asbestos, the production of coal gas, and probably the manufacture of substances containing inorganic arsenic (Bignall, 1958b), and working with tar, oil, varnish, and certain hot metals and metallic dusts (Stocks, 1959b). The only patient in the series concerned with one of these was a coal gas worker, and he also smoked about 20 cigarettes per day.

The number engaged in individual occupations in the area is not known, and the incidence of bronchial carcinoma in different occupations cannot be calculated. As expected in a rural area, there were more outdoor than indoor workers $(1.6: 1.0)$. In contrast, in the London area Bryson and Spencer (1951) found a slightly greater proportion of indoo: to outdoor workers $(1.3: 1.0)$.

It was possible to analyse in detail the smoking habits of 92 of the 100 rural cases of bronchial carcinoma (Table III).

TABLE III

DISTRIBUTION BY SMOKING HABIT

\begin{tabular}{|c|c|c|c|c|c|c|c|}
\hline \multirow{2}{*}{$\begin{array}{c}\text { Age of } \\
\text { Detecting } \\
\text { Bronchial } \\
\text { Carcinoma }\end{array}$} & \multicolumn{2}{|c|}{ No. } & \multicolumn{2}{|c|}{ Non-smokers } & \multicolumn{3}{|c|}{$\begin{array}{c}\text { Smoking a Daily* } \\
\text { Average of }\end{array}$} \\
\hline & Males & Females & Males & Females & $1-14 \mathrm{~g}$. & $15-24 \mathrm{~g}$ & $\begin{array}{c}25 \mathrm{~g} . \text { or } \\
\text { More }\end{array}$ \\
\hline $\begin{array}{cc}\text { Under } & 35 \\
\text { years } & \ldots \\
35-44 & \ldots \\
45-54 & \ldots \\
55-64 & \ldots \\
65-74 & \ldots \\
\text { Over 74 } & \ldots\end{array}$ & $\begin{array}{r}1 \\
7 \\
22 \\
43 \\
10 \\
2\end{array}$ & $\begin{array}{l}1 \\
2 \\
3 \\
1 \\
0 \\
0\end{array}$ & $\begin{array}{l}0 \\
0 \\
0 \\
0 \\
0 \\
0\end{array}$ & $\begin{array}{l}0 \\
0 \\
2 \dagger \\
0 \\
0 \\
0\end{array}$ & $\begin{array}{r}1 \\
2 \\
7 \\
13 \\
4 \\
0\end{array}$ & $\begin{array}{r}0 \\
3 \\
12 \\
16 \\
4 \\
2\end{array}$ & $\begin{array}{r}1 \\
4 \\
4 \\
15 \\
2 \\
0\end{array}$ \\
\hline All ages .. & $\begin{array}{l}85 \\
\text { Total }\end{array}$ & $\begin{array}{r}7 \\
92\end{array}$ & $\begin{array}{c}0 \\
(0.0 \%)\end{array}$ & $(2 \cdot 2 \%)$ & $\begin{array}{l}27 \\
(29 \cdot 3 \%)\end{array}$ & $\begin{array}{c}37 \\
(40 \cdot 2 \%)\end{array}$ & $\begin{array}{l}26 \\
(28 \cdot 3 \%)\end{array}$ \\
\hline
\end{tabular}

* Only three pipe smokers. † Both undifferentiated carcinomas. One cigarette $=1 \mathrm{~g}$. tobacco.

In a Medical Research Council's statement (1957) a relationship between smoking and bronchial carcinoma was acknowledged. The report concluded from evidence from many investigations in different countries that a major part of the very great increase in lung cancer is associated with tobacco smoking, particularly in the form of cigarettes.

Differences in smoking habits in general between town and country are not marked. Earlier im- pressions that there were appreciably more smokers and proportionately more heavy smokers in highly urbanized communities have not been substantiated. Even when the difference seemed greater, it was still insufficient to account for the discrepancy between the rural mortality and that of large towns (Doll and Hill, 1952). Accounts of smoking habits are difficult to evaluate and to compare. The type of population on which they are based varies, and findings are not usually truly representative of a community as a whole. The actual amount and duration of smoking are usually incompletely assessed, and there is lack of conformity in the mode of presentation. With reservations, however, comparable trends can be seen.

In urban areas $70.9 \%$ of men aged 25 years and over working in factories in Birmingham who attended for mass radiography were current smokers (Cross, McDowell, and Posner, 1958); $92 \%$ of men aged 30 years and over who attended an accident hospital out-patient department, or were in-patients in a general hospital, also in Birmingham, were sometime-predominantly current-smokers (Lowe, 1956); and $85.5 \%$ of doctors aged 35 years and over in Greater London and large towns were at some time smokers (Doll and Hill, 1956).

In rural areas $68 \%$ of men aged 25 years or over attending for mass miniature radiography in Herefordshire and Shropshire were current smokers (Cross et al., 1958); $74 \%$ of males aged 25 to 74 years in the Vale of Glamorgan were current smokers, and $91 \%$ at some time smokers (Higgins, 1957 ); and $79 \%$ of males aged 55 to 64 years in Annandale were current smokers, and $93 \%$ at some time smokers (Higgins, 1959).

In a hospital population of men 25 to 74 years of age, the standardized percentage of smokers in town and country was 94.9 and 89.6, respectively (Doll and Hill, 1952).

In random samples of the population in the urban areas of Rhondda Fach and Leigh, in the rural areas of the Vale of Glamorgan, and in Annandale, Higgins (1959) found no striking differences on comparing the smoking habits of men primarily between the ages of 55 and 64 years. There was a slightly higher proportion both of heavy smokers and of ex-smokers in the two rural areas. The similarity of the total tobacco consumption in the Vale of Glamorgan and in Annandale in the samples studied (Higgins and Cochran, 1958) is of special interest, Annandale being a typical rural part of Dumfries and Galloway.

Among doctors, a relatively homogeneous but special section of the population, remarkably little difference was found between the smoking habits of 
TABLE IV

TOBACCO CONSUMPTION OF SMOKERS IN TOWN AND COUNTRY

\begin{tabular}{|c|c|c|c|}
\hline & \multicolumn{3}{|c|}{$\begin{array}{l}\text { Percentage No. of Con- } \\
\text { sumers Smoking a Daily } \\
\text { Average of }\end{array}$} \\
\hline & $1-14 \mathrm{~g}$. & $15-24 \mathrm{~g}$. & \begin{tabular}{|c|c|c|c|}
25 g. or \\
More
\end{tabular} \\
\hline 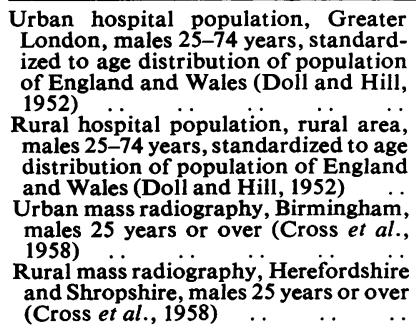 & $\begin{array}{l}60 \cdot 7 \\
46 \cdot 1 \\
46 \cdot 5\end{array}$ & $\begin{array}{l}42 \cdot 1 \\
41 \cdot 0\end{array}$ & 15.4 \\
\hline
\end{tabular}

One cigarette $=1 \mathrm{~g}$. tobacco.

the residents in the different areas, the tendency being for more non-smokers and fewer heavy smokers to be found in the large urban communities (Doll and Hill, 1956).

The tobacco consumption of the 85 males in the present rural series with bronchial carcinoma and whose smoking habits are known is greater than that of a general population in these town and country surveys. Indeed, it is even somewhat greater than that of 1,357 patients with bronchial carcinoma in the urban series of Doll and Hill (1952), and appreciably greater than their control patients with other diseases. A direct comparison is not entirely valid. Doll and Hill defined their smoking habits as " the most recent amount smoked," while the smoking habit in the present series is basically the current habit. The difference is not as great as it might have been; when the current smoking was known to be markedly different from an earlier one, the habit recorded is the predominant one in adult life.

TABLE V

TOBACCO CONSUMPTION IN URBAN AND RURAL PATIENTS COMPARED

\begin{tabular}{|c|c|c|c|c|}
\hline & \multirow{2}{*}{$\begin{array}{l}\text { Per- } \\
\text { centage } \\
\text { Non- } \\
\text { smokers }\end{array}$} & \multicolumn{3}{|c|}{$\begin{array}{c}\text { Percentage Smoking a } \\
\text { Daily Average of }\end{array}$} \\
\hline & & $1-14 \mathrm{~g}$. & $15-24 \mathrm{~g}$ & $\begin{array}{l}25 \mathrm{~g} . \text { or } \\
\text { More }\end{array}$ \\
\hline $\begin{array}{l}\text { Urban males } 25-74 \text { years, with } \\
\text { bronchial carcinoma, Greater } \\
\text { London and } 4 \text { provincial towns, } \\
\text { (Doll and Hill, 1952) } \\
\text { Control patients, with other } \\
\text { diseases, Greater London and } \\
4 \text { provincial towns (Doll and }\end{array}$ & 0.5 & $41 \cdot 6$ & $32 \cdot 8$ & $25 \cdot 0$ \\
\hline $\begin{array}{l}\text { Hill, 1952) } \\
\text { Rural } \\
\text { males basically } \\
\text { years, with bronchial carcinoma } \\
\text { (present series) }\end{array}$ & 0.0 & $28 \cdot 2$ & $42 \cdot 4$ & $29 \cdot 3$ \\
\hline
\end{tabular}

One cigarette $=1$ g. tobacco.
Although the portion of tissue examined is usually small, bronchoscopic biopsy gives the best opportunity clinically for firm diagnosis and for the determination of the histological type. In the present series the histological nature of the carcinoma was determined in $78 \%$ of the cases by bronchoscopic biopsy in $67 \%$ and by thoracotomy alone in $11 \%$.

TABLE VI

DISTRIBUTION ACCORDING TO HISTOLOGICAL TYPE

\begin{tabular}{|c|c|c|c|}
\hline \multicolumn{3}{|l|}{ Histological Type } & Number of Cases \\
\hline $\begin{array}{l}\text { Squamous carcinoma } \\
\text { Undifferentiated carcinoma } \\
\text { Adenocarcinoma }\end{array}$ & $\begin{array}{l}\cdots \\
\cdots \\
\cdots\end{array}$ & $\begin{array}{l}\cdots \\
\cdots \\
\cdots\end{array}$ & $\begin{array}{rc}38 & (48 \cdot 7 \%) \\
35 & (44 \cdot 9 \%) \\
5 & (6 \cdot 4 \%)\end{array}$ \\
\hline & IdI & $\cdots$ & $78(100 \cdot 0 \%)$ \\
\hline
\end{tabular}

The histological pattern of bronchial carcinoma is well recorded in urban series.

TABLE VII

PERCENTAGE DISTRIBUTION HISTOLOGICALLY IN URBAN SERIES

\begin{tabular}{|c|c|c|c|c|}
\hline Author & Source & $\begin{array}{l}\text { Squamous } \\
\text { Carcinoma }\end{array}$ & $\begin{array}{l}\text { Undiffer- } \\
\text { entiated } \\
\text { Carcinoma }\end{array}$ & $\begin{array}{l}\text { Adeno- } \\
\text { carcinoma }\end{array}$ \\
\hline Mason (1949) & $\begin{array}{l}\text { North of Eng- } \\
\text { land and } \\
\text { Midlands }\end{array}$ & $44 \cdot 8$ & $45 \cdot 9$ & $9 \cdot 3$ \\
\hline $\begin{array}{l}\text { Bryson and } \\
\text { Spencer (1951) }\end{array}$ & $\begin{array}{l}\text { Greater } \\
\text { London }\end{array}$ & $\begin{array}{c}18 \cdot 1 \\
\text { (including } \\
11 \cdot 2 \\
\text { squamoid) }\end{array}$ & $76 \cdot 2$ & 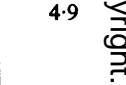 \\
\hline Kreyberg (1952) & Oslo & 56.0 & $31 \cdot 0$ & $\begin{array}{c}9.0 \\
(\operatorname{mixed} 5 \cdot 0)\end{array}$ \\
\hline $\begin{array}{l}\text { Bignall and } \\
\text { Moon (1955) }\end{array}$ & $\begin{array}{l}\text { London } \\
\text { (operation } \\
\text { survivors) }\end{array}$ & $60 \cdot 7$ & $26 \cdot 0$ & $13 \cdot 3$ \\
\hline Bignall (1955) & $\begin{array}{l}\text { London (un- } \\
\text { suitable for } \\
\text { surgery or } \\
\text { radio- } \\
\text { therapy) }\end{array}$ & $56 \cdot 5$ & $34 \cdot 9$ & $8 \cdot 5$ \\
\hline $\begin{array}{l}\text { Nicholson } \\
\text { et al. (1957) }\end{array}$ & Manchester & $56 \cdot 0$ & $37 \cdot 0$ & $6 \cdot 0$ \\
\hline Bignall (1958c) & $\begin{array}{l}\text { London } \\
\text { (resected } \\
\text { specimens) }\end{array}$ & $56 \cdot 0$ & $33 \cdot 0$ & $11 \cdot 0$ \\
\hline
\end{tabular}

The percentage distribution of the various types of bronchial carcinoma is consistent in most of these urban series and similar to that found in this rural series. Even when discrepancies occur, they may be largely due to a difference in interpretation of cells: a variety of opinions could undoubtedly be obtained on some of the sections. Also, a variable histological pattern not infrequently occurs in individual tumours (Kreyberg, 1952; Willis, 1953). Dr. Agnes L. Scott reviewed the histology of all the bronchial biopsies for a second time on completion of the present series to ensure standard reporting throughout.

From a clinical viewpoint discrepancies between the proportion of squamous cell carcinoma and undifferentiated carcinoma possibly have no real 
significance, and likewise similar discrepancies between town and country series. Much can be said for considering both as one group. Evidence suggests that the relationship between smoking and bronchial carcinoma only holds for these types (Kreyberg, 1955; Doll and Hill, 1956), for women as well as for men. The risk of developing epidermoid cancer of the lung or its undifferentiated types among women who smoke is about the same as that of men (Wynder, 1957).

Adenocarcinomas are thought to stand apart; they do not appear to be associated with smoking (Kreyberg, 1955; Wynder, Bross, Cornfield, and O'Donnell, 1956). They are divided almost equally between the sexes, possibly with a slight predominance in men (Lancet, 1957), and they form a higher proportion of all lung tumours in women (Bignall and Moon, 1955; Nicholson et al., 1957; Bignall, 1958d).

7 he proportion of adenocarcinomas in the present rural series is similar to that in urban series, but five occurred in males and only one in a female. Two smoked one to 14 cigarettes, and three over 25 cigarettes, daily.

\section{Clinical Features}

The clinical features of the cases were not sufficiently outstanding to warrant detailed analysis. The manner of presentation and the stage of the illness when detected were similar to that seen personally in other patients in Edinburgh and Glasgow. Thoracotomy was carried out in $24 \%$ of the cases. Radiotherapy was only given to a few. It could only have been palliative, and the patients had to travel long distances to receive it. In keeping with general trends, life expectancy was short by the time the cases presented, $20 \%$ being alive at the end of the period of review. Only 13 of these survivors presented over six months ago, one five to six years ago, three three to four years ago, one two to three years ago, and the remainder six months to two years ago. In 10 of these 13 cases where the type of carcinoma is known, seven were squamous and three undifferentiated.

\section{ConClusions}

Bronchial carcinoma in this rural series showed no special features to distinguish it from that described in towns. No difference in distribution by sex and age was found. No occupation in the country was obviously associated with a high incidence of the disease. There were more outdoor than indoor workers. While no doubt this simply reflects the nature of work locally, it has an important implication: bronchial carcinoma can occur not infrequently in outdoor workers accustomed to negligible or minimal air pollution, and not exposed to any known hazard other than cigarette smoking. The relationship between smoking and bronchial carcinoma seems to hold in the country as in the town. In these patients with bronchial carcinoma the percentage of smokers is high, the amount of tobacco consumed is at least as great as in a large urban series, and the histological types of carcinoma thought to be related to smoking were found in the same proportion as in towns. The relative distribution of squamous carcinomas, undifferentiated carcinomas, and adenocarcinomas was similar to that in several urban series. The clinical pattern of bronchial carcinoma was the same as in towns.

\section{SUMMARY}

One hundred cases of bronchial carcinoma arising in a rural area were examined for any significant differences in the disease as described in towns. Even though this is a non-industrial area, and atmospheric pollution is extremely low, no outstanding difference was found. The relationship between smoking and bronchial carcinoma seems to hold in the country as in the town.

We are grateful to Dr. Christopher Clayson for his interest and help throughout, and to Dr. Agnes L. Scott for specially reviewing the bronchial biopsies.

\section{REFERENCES}

Bignall, J. R. (1955). Lancet, 2, 210.

(1958a). Carcinoma of the Lung, p. 20. Livingstone, Edinburgh and London.

(1958b). Ibid., p. 58.

(1958c). Ibid., p. 115.

(1958d). Ibid., p. 184.

and Moon, A. J. (1955). Thorax, 10, 183

Bryson, C. C., and Spencer, H. (1951). Quart. J. Med., $20,173$.

Cross, K. W., McDowell, L. A., and Posner, E. (1958). Brit. med. J., 1,862 .

Doll, R., and Hill, A. B. (1952). Ibid., 2, 1271.

Dor, (1956). Ibid., 2, 1071.

Higgins, I. T. T. (1957), Ibid., 2, 1198.

(1959). Ibid., 1, 325 .

Kre and Cochran, J. B. (1958). Tubercle (Lond.), 39, 296.

Kreyberg, L. (1952). Brit. J. Cancer, 6, 112.

(1955). Ibid., 9, 495 .

Lancet (1957), 1, 571 [Leading article].

Lowe, C. R. (1956). Brit. med. J., 2, 1081.

Mason, G. A. (1949). Lancet, $2,587$.

Medical Research Council (1957). Brit. med. J., 1, 1523.

Nicholson, W. F., Fox, M., and Bryce, A. G. (1957). Lancet, 1, 296.

Stocks, P. (1959a). Brit. med. J., 1, 74.

Will (1959b). Practitioner, 182, 667.

Willis, R. A. (1953). Pathology of Tumours, 2nd ed., p. 367. Butterworth, London.

Wynder, E. L. (1957). Brit. med. J., 1, 1.

Bross, I. J., Cornfield, J., and O'Donnell, W. E. (1956). New 